\title{
Mechanism for signal transduction in the induced-raft domains as revealed by single-molecule tracking
}

\section{1 分子追跡が明らかにした誘導ラフト領域におけるシグナル変換機構}

\author{
Suzuki, Kenichi G. N.1,2; and Kusumi, Akihiro ${ }^{2,3}$ \\ ${ }^{1}$ Precursory Research for Embryonic Science and Technology (PRESTO), \\ Japan Science \& Technology Agency (JST), \\ ${ }^{2}$ Institute for Integrated Cell-Material Sciences (iCeMS), Institute for Frontier Medical Sciences, \\ Kyoto University, Kyoto, 606-8507 Japan, \\ ${ }^{3}$ Membrane Mechanism Protect, International Cooperative Research Project (ICORP), \\ Japan Science \& Technology Agency (JST) \\ FAX: + 81-75-751-4113, E-mail: ksuzuki@frontier.kyoto-u.ac.jp
}

(Received on September 23, 2008, accepted on September 25, 2008)

Key Words: single-molecule tracking, plasma membrane, membrane skeleton, signal transduction, induced raft domain

\begin{abstract}
Raft domains have been proposed to work as a platform where raftophilic signaling molecules assemble and interact for efficient signal transduction. However, this raft hypothesis has been difficult to prove. Our recent single-molecule tracking experiments revealed that cytoplasmic signaling molecules were frequently, but very transiently recruited to the rafts formed on demand by the clusters of raftophilic glycosylphosphatidylinositol (GPI)anchored receptors (e.g., CD59) that were generated after the engagement of the receptors by the binding of extracellular signaling molecules. All of the cytoplasmic signaling molecules examined thus far, Goi2, Lyn, and PLC $\gamma$, exhibited short residency times of $\sim 200 \mathrm{~ms}$ within the CD59-cluster rafts. This recruitment period of each individual signaling molecule was short, compared with the periods of overall bulk activation of these molecules by a factor of 4,000. Argument has been advanced that the analogue bulk signal, which lasts for over several thousands seconds, is generated by the superposition of the short-lived, digital-like individual signals, which last for a fraction of a second.
\end{abstract}

\section{A. Introduction}

In recent years, so-called raft hypothesis, initially conceived and proposed by Simons and van Meer (1) and Simons and Ikonen (2), has attracted extensive attention as a platform for signal transduction on the plasma membrane. According to the raft hypothesis, upon the reception of extracellular queues by raftophilic receptors in the plasma membrane (receptors are often considered to parti-
要 約

ラフトドメインは, 分子が効率的にシグナル伝達を行う ために集まり，相互作用するプラットフォームであると提案 されている。最近我々は 1 分子追跡実験により, 細胞外シグ ナル分子の結合による受容体刺激後に形成された，グリコシ ルホスファチジルイノシトール（GPI）アンカー型受容体 （例えばCD59）のクラスターにより，オンデマンドに形成さ れるラフトへ, 細胞質側のシグナル分子がしばしば，しかし 非常に一時的にリクルートされることを明らかにした。今ま でに調べたすべての細胞質側のシグナル分子, Goi2, Lyn, PLC $\gamma$ は，CD59 クラスターラフト内で〜200ミリ秒の短い滞 在時間を示していた。各々のシグナル分子のリクルート期間 は，これらの分子全体のバルクの活性化期間と比較して 4000 倍も短かった。数千秒以上もの間続くアナログ型のバルクシ グナルが，1 秒以下しか続かない短寿命のディジタル式の個々 のシグナルの重ね合わせにより生み出されていることについ て議論を進めた。

\section{A. はじめに}

Simons と van Meer ら (1), そして Simons とIkonen ら (2)により最初に提案されたラフト仮説は, 形質膜上のシグナ ル伝達のためのプラットフォームとして近年非常に注目され ている。ラフト仮説によると, 形質膜上のラフト様受容体 （細胞を低温下で Triton 処理し超遠心後に, 受容体が低密度画 分に回収されれば，その受容体は形質膜上のいわゆるラフト 


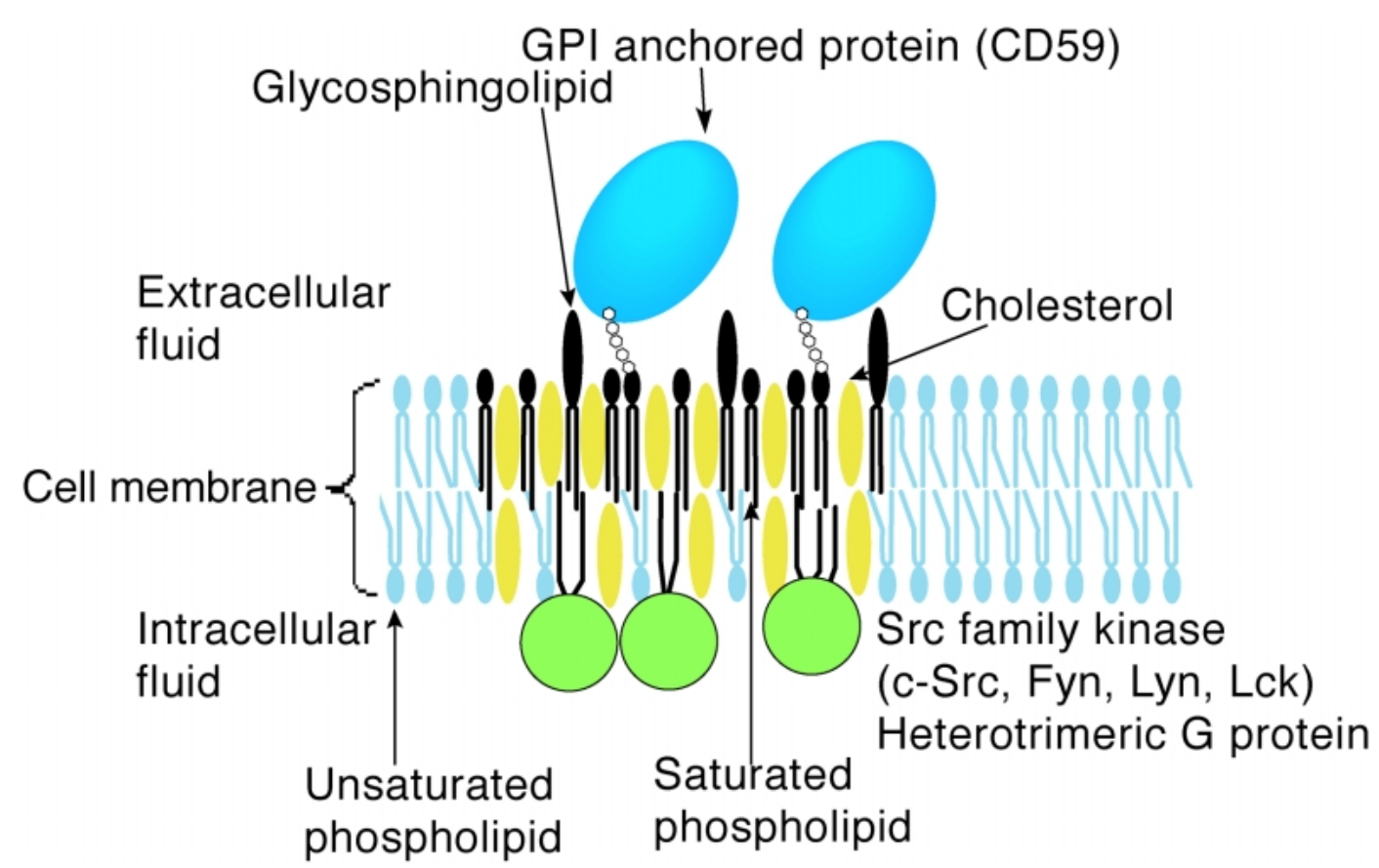

Fig. 1. A schematic drawing of the hypothetical composition and structure of the raft domains.

tion into so-called raft domains in the plasma membrane if they are recovered in the low-density fraction by ultracentrifugation after cold-Triton treatment of the cell, and therefore, these receptors are called raftophilic in this review), these receptors as well as raftophilic intracellular lipid-anchored signaling molecules assemble in the pre-existing rafts or form new stabilized rafts, where, due to higher concentrations of the molecules in the stabilized rafts, the raftophilic signaling molecules efficiently interact with each other to carry out signal transduction, involved in, to name a few, cell growth (3), cell adhesion $(4,5)$, neuronal activity $(6-8)$, and immunological responses $(9,10)$. Raft domains are considered to be enriched in glycosphingolipids (11-14), cholesterol (15), glycosylphosphatidylinositol (GPI)-anchored proteins (16) in the outer leaflet, and in lipid (saturated fatty acid)-anchored signaling molecules such as heterotrimeric $\mathrm{G}$ proteins and Src family kinases (SFKs) (17), in the inner leaflet (Fig. 1).

About $10 \%$ of the signal receptors in the plasma membrane are considered to be anchored to the plasma membrane by way of the covalent linkage to a phospholipid, called glycosylphosphatidylinositol or GPI (18), and therefore, these receptors are called GPI-anchored receptors (GPI-ARs), or GPI-anchored proteins. Since these GPI-ARs are not exposed to the cytoplasmic surface of the plasma membrane, how GPI-anchored receptors transduce signals from the outside world to the inside of the cell has been a long-standing enigma (17). In recent
ドメインへ分配されていると考えられている。従って，この 総説ではこれらの受容体をラフト様受容体と呼んでいる）に よって細胞外のシグナルが受け取られると, これらの受容体 は, ラフト様の細胞内脂質アンカー型シグナル分子と同様 に，刺激前から存在するラフト中に集まってくるか，新しい 安定化ラフトを形成する。この安定化ラフトに抢いて, ラフ ト様シグナル分子の濃度が高くなるために, 抢互いの分子が 効率よく相互作用し，シグナル伝達を行う。例えばラフトに 関連したシグナル伝達の例を 2,3 挙げると, 細胞の増殖 (3), 細胞接着 $(4,5)$, 神経活動 $(6-8)$, 免疫反応 $(9,10)$ などが ある。膜の外層のラフトドメインにはスフィンゴ糖脂質 (1114), コレステロール(15), グリコシルホスファチジルイノシ トール（GPI） アンカー型タンパク質(16)などが，内層のラ フトドメインには三量体 G タンパク質や Src ファミリーキ ナーゼ（SFK）（17）など脂質（飽和脂肪酸）アンカー型シグ ナル分子が濃縮されていると考えられている（図 1)。

ところで，細胞形質膜上の受容体のうち約 10\% は，GPI （18）と呼ばれるリン脂質に結合することにより細胞膜にアン カーされていると考えられて抢り, 従って, これらの受容体 は GPI アンカー型受容体 (GPI-ARs), あるいは GPIアンカー 型タンパク質と呼ばれている。これらの GPI-ARs は細胞膜内 側に露出していないので, GPI-ARs がどのようにして細胞外 からのシグナルを細胞内に伝えているのかが長い間疑問であ った(17)。近年, GPI-ARs のシグナル伝達はラフトを介して 
years, many researchers started to believe that the signal transduction of GPI-ARs is carried out in raft domains, but how this is done is totally unknown.

Recently, we approached this problem by using single-molecule tracking techniques we developed and advanced. These techniques are extremely useful for tracking movement, distribution, interaction of two or three molecules, and the reaction of molecules at the level of single molecules in living cells (19-22). We applied this technique to the study of signal transduction via GPI-ARs by observing the behavior of GPI-ARs and several cytoplasmic signaling molecules upon the engagement of GPI-ARs $(23,24)$. In the present review, we briefly summarize the methods employed and the results obtained in this research.

\section{B. GPI-anchored receptors form cluster-rafts upon stimu- lation}

As a prototypical GPI-AR, we employed CD59, the receptor for the eighth component of the complement (C8), which works at the first step in the signaling pathway of protecting cells against the self-attack of the complement system. Upon the addition of C8, CD59 forms clusters, which trigger the signal transduction (Fig. 2(1)).
起きているかもしれないと多くの研究者が信じ始めている が，これがどのようにして起こるのかは全くわかっていない。

最近我々は, 自ら開発した 1 分子追跡法を用いて, これ らの課題に取り組んでいる。これらの手法は, 分子の運動, 分布や, 2 分子または 3 分子間の相互作用や, 分子の反応(1922)を, 生きている細胞膜上で 1 分子レベルで追跡するのに極 めて有益である。我々は GPI-ARs 刺激後の GPI-ARs と細胞 質側のシグナル分子の挙動を同時に 1 分子観察すること $(23,24)$ により, GPI-ARsによるシグナル伝達の研究を行っ た。この総説では, 我々の研究で用いられた手法とそこで得 られた結果を簡単にまとめる。

B. 刺激によって GPI アンカー型受容体はクラスターラフトを 形成する

典型的 GPI-AR として, 我々は, 自己の補体による攻撃 から細胞を守るシグナル経路の最初にある受容体である CD59 という補体の第 8 成分 $(\mathrm{C} 8$ ) の受容体を用いた。C8 を添加す るとCD59 は会合し, シグナル伝達を誘導する（図 2(1)）。

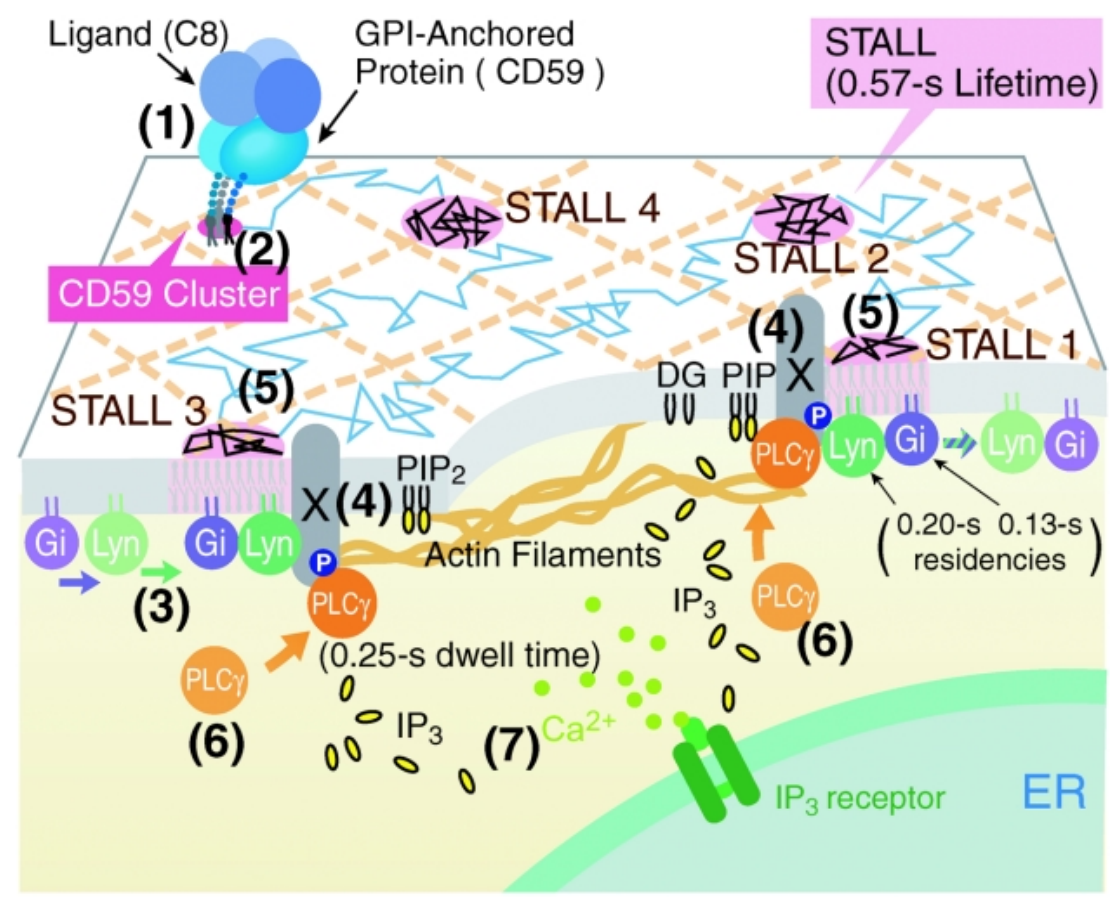

Fig. 2. CD59-cluster rafts trigger intracellular signaling at STALLed sites. A working model showing how STALL of the CD59-cluster raft might be induced and how it might function as a transient platform for transducing the extracellular CD59 signal to the intracellular $\mathrm{IP}_{3}-\mathrm{Ca}^{2+}$ signal (via PLC $\gamma 2$ recruitment to STALLed CD59-cluster raft). See the text for further details. 
(a) Fab-Gold

Fab-Gold +

Crosslinking

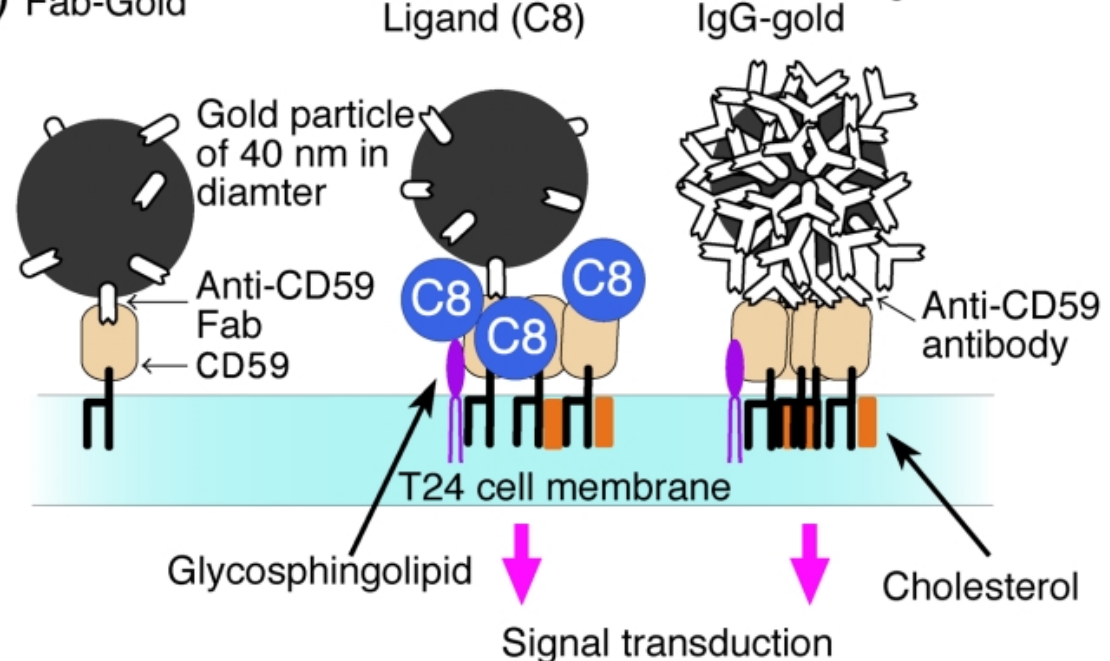

(b)
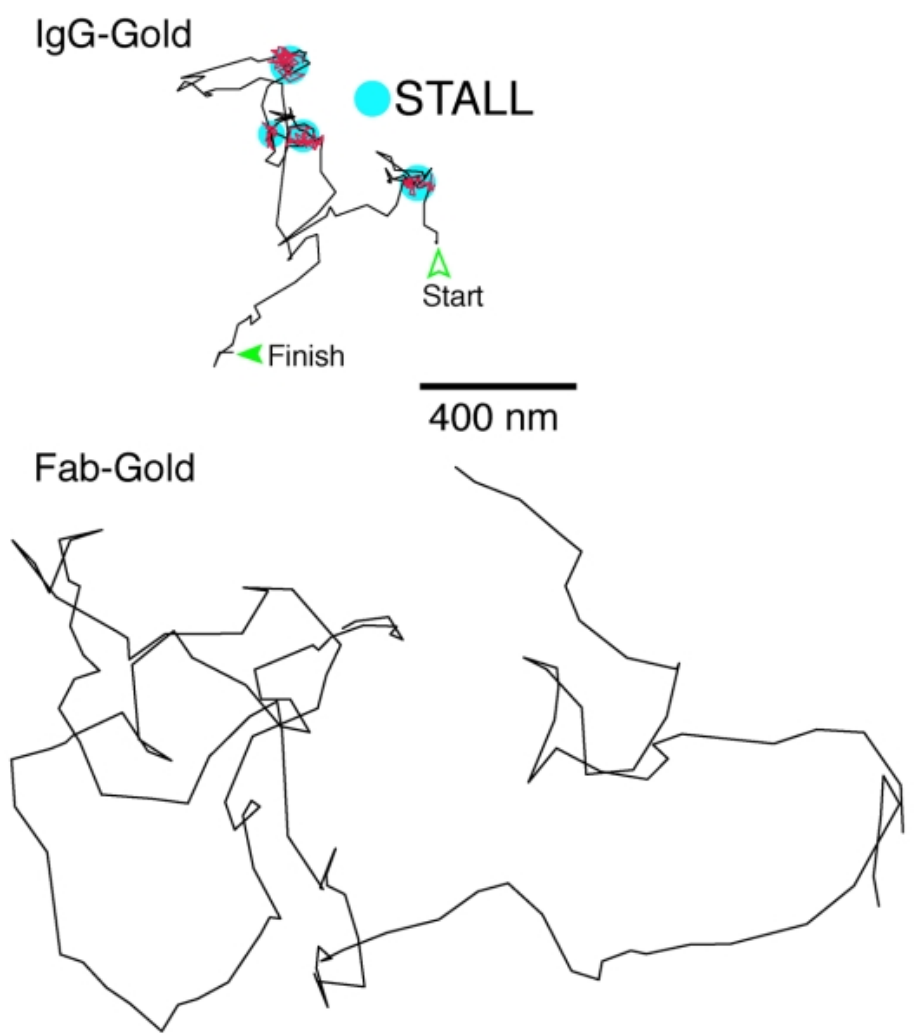

Fig. 3. CD59-cluster rafts undergo alternating periods of STALL and apparent, simple-Brownian diffusion. (a) Stimulation of CD59 with IgG-Gold, or C8-Fab-Gold induces clustering of CD59, which then turn into CD59-cluster rafts. (b) (Top trajectory) A typical trajectory of IgG-Gold recorded for $10 \mathrm{~s}$ at video rate. CD59-cluster rafts exhibit alternating periods of apparent, simple-Brownian diffusion (black trajectories) and STALL (magenta trajectories in the circular blue areas). (Bottom trajectory) A representative trajectory of Fab-Gold recorded for 5 seconds at video rate, shown for the comparison with those of IgG-Gold. 
By the same token, directly crosslinking CD59 with $40 \mathrm{~nm}$-colloidal gold particles coated with many molecules of anti CD59 immunoglobulin G (IgG-Gold, Fig. 3a) also induced intracellular signaling such as $\mathrm{IP}_{3}$ production, calcium mobilization, and SFK activation. We used the condition in which an average of six molecules of CD59 were clustered underneath a gold particle, and approximately 600 such CD59 clusters were formed on the basal plasma membrane: namely 3,600 copies of CD59 per cell were engaged. These experimental conditions were selected, because the intracellular signaling was triggered very robustly under these conditions, and the diffusional movement of gold particles that crosslinked six CD59 molecules were similar to that of CD59 clusters induced by the binding of the natural ligand C8. Interestingly, the CD59-cluster-induced signaling was blocked by cholesterol depletion, and reinstated by the subsequent repletion of cholesterol, suggesting that these CD59 clusters induced raft-like domains within the cluster (Fig. 2(1)(2)). Hence, the IgG-Gold-induced CD59 clusters are called CD59-cluster rafts.

\section{Extremely anomalous diffusion of CD59-cluster rafts: Stimulation-induced Temporary Arrest of LateraL diffusion $=$ STALL}

The behaviors of single individual CD59-cluster rafts, observed at video rate $(33 \mathrm{~ms} /$ frame), were extremely peculiar. They exhibited alternating periods of apparent simple-Brownian diffusion (with the effective diffusion coefficient in the 100-ms window smaller than that of non-stimulated CD59 by a factor of 8) and temporary immobilization. Both lengths of simple-Brownian and immobilized periods exhibited exponential distributions, with lifetimes of 1.2 and $0.57 \mathrm{~s}$, respectively (Fig. 3b). Since the plasma membrane is like a two-dimensional liquid, the temporary immobilization was totally unexpected, and named Stimulation-induced Temporary Arrest of LateraL diffusion or STALL (Fig. 2(5)). STALL would have been difficult to find by the methods to observe the ensemble-averaged behavior of many molecules, such as FRAP (fluorescence recovery after photobleaching) or FCS (fluorescence correlation spectroscopy).

After treatments like partial cholesterol depletion, partial actin depolymerization, or blocking of the activity of SFKs, or Goi, STALL as well as $\mathrm{IP}_{3}$-calcium signaling almost disappeared. Based on these results, we hypothesized that STALL was induced by the binding of CD59cluster raft to the actin-based membrane skeleton, which might be triggered by Goi activation, which induced SFK activation. This hypothesis is consistent with the previous results obtained by optical tweezers $(25,26)$.
同様に多くの抗 CD59 IgG 抗体で被覆した直径 $40 \mathrm{~nm}$ の 金粒子（IgG-Gold, 図 3a）でCD59を集合させても, IP 3 産 生やカルシウム応答, SFK 活性化などの細胞内シグナルが誘 起されていた。 1 個の金粒子直下に平均 6 個の CD59 分子が会 合され，このような CD59 クラスターの 600 個が細胞膜上に 形成される条件，つまり細胞あたり 3600 個の CD59 分子が刺 激されるという条件を用いた。この条件下で, 細胞内のシグ ナルは非常に安定して起こり, CD59の6 分子をクロスリンク する金粒子の拡散運動は, リガンド C 8 結合により誘導された CD59 クラスターの拡散運動に近かったために, 我々はこの実 験条件を選んだ。興味深いことに，CD59 クラスターが誘起し たシグナルは, コレステロール除去により阻害され, 引き続 きコレステロールを戻すことによって回復していた。これは， CD59 クラスターがクラスター内にラフト様ドメインを誘起し たことを示唆している（図 2(1) (2))。従って, IgG-Gold が誘 起したCD59 クラスターをCD59 クラスターラフトと呼んで いる。

C. CD59 クラスターラフトの極めて異常な拡散挙動：STALL ビデオレート (33ミリ秒/フレーム) で観察された個々の CD59 クラスターラフトの挙動は極めて奇妙なものであった。 見かけ上の単純ブラウン運動（100ミリ秒の時間スケールでの 拡散係数は刺激前のCD59の場合の 8 倍小さい） と一時停留 の期間を繰り返していた。単純ブラウン運動と一時停留の期 間の長さは両方とも指数関数分布を示しており，それぞれ 1.2 秒, 0.57 秒の寿命を持っていた（図 $3 b)$ 。細胞膜は 2 次元の 液体状であるので, この一時停留は全く予想外であった。こ

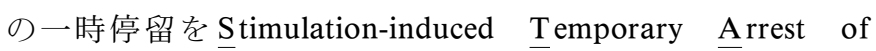
LateraL diffusion あるいはSTALL と名づけた（図 2(5))。多 数分子のアンサンブル平均の挙動を調べる方法, 例えば, FRAP（蛍光退色回復法）やFCS（蛍光相関法）などでは,

STALLを見つけ出すことは難しかったであろう。

細胞膜からコレステロールを部分除去したり，アクチン 繊維を部分破壞したり，SFK や Goi の活性を阻害すると， IP 3 一カルシウムシグナルとともに STALL がほとんど消失してい た。これらの結果に基づいて我々は, Goi の活性化によって SFK が活性化され，その活性化が CD59 クラスターラフトの アクチン膜骨格への結合を誘起し, STALLが誘起されるとい う仮説を立てた。この仮説は光ピンセットにより得られた以 前の結果とも一致している $(25,26)$ 。 


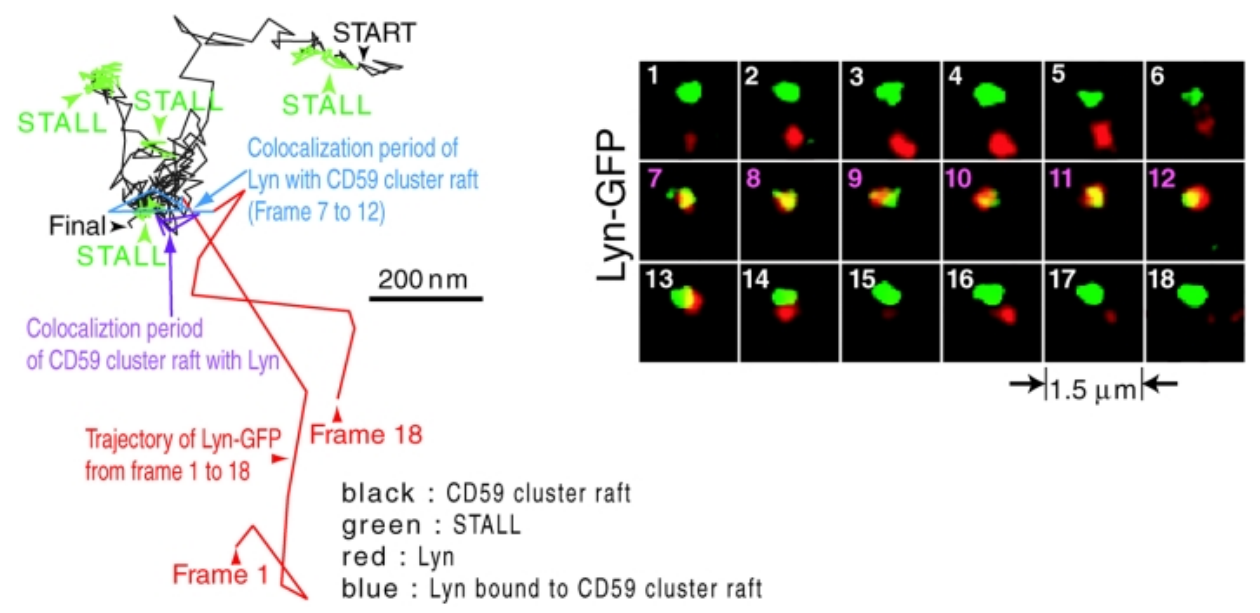

Fig. 4. Simultaneous observations of individual CD59-cluster rafts and individual Lyn-GFP molecules. Right. Image sequences showing superimposed video frames of simultaneous recordings of a CD59-cluster raft (green spot) and single molecules of LynGFP (red spot). A single Lyn-GFP molecule was colocalized from frame 7 until 12 (pink frame numbers). Left. A typical trajectory of a CD59-cluster raft (black), including STALL periods (the green parts of the trajectories) and a period (the purple parts of the trajectories) in which it was colocalized with Lyn-GFP (blue part in the otherwise magenta trajectory; it overlaps with a STALL site, but at different times).

a

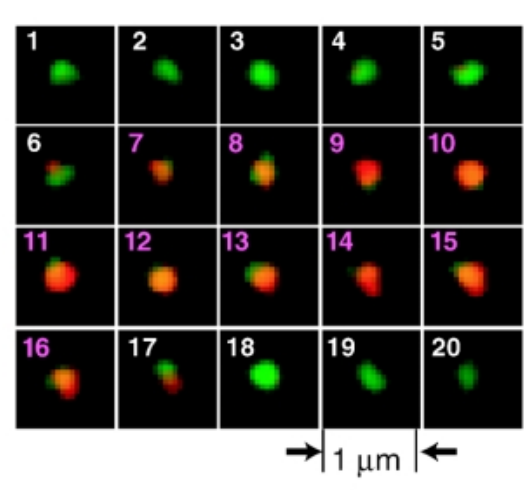

b

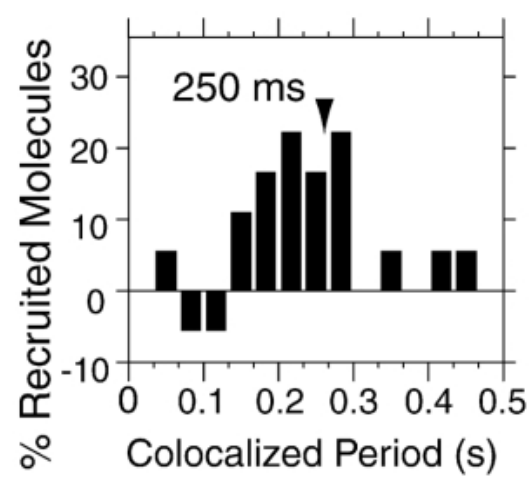




\section{Transient recruitment of intracellular signaling molec- ules to CD59-cluster raft}

Simultaneous observations of individual CD59cluster rafts and each single copy of intracellular signaling molecules conjugated to GFP (Lyn-GFP, Goi2-YFP, and GFP-PLC $\gamma 2$ ) were achieved, using the instruments and methodologies developed in our laboratory (transient recruitment of Lyn-GFP to CD59 cluster is shown in Fig. 4). This difficult experiment handsomely paid off, leading to the following interesting observations (Fig. 2, Fig. 4). Lyn molecules were constitutively and frequently recruited to the diffusing CD59-cluster raft (Fig. 2(3)). Gai2 molecule was also recruited to the CD59-cluster raft, and right after the recruitment of Goi2, STALLing of the CD59cluster raft was induced. Since Goi2 is known to directly activate SFKs, it is likely that when Goi2 and Lyn molecules are recruited to the same CD59-cluster raft (Fig. 2(3)), Goir2 would bind to Lyn, activating Lyn, which in turn would phosphorylate as-yet unknown transmembrane protein X (see Fig. 2(4)), leading to the binding of the CD59-cluster raft to actin filaments, immobilizing the CD59-cluster raft, i.e., STALLing the CD59-cluster raft (Fig. 2(5)).

Furthermore, PLC $\gamma 2$, which is an enzyme involved in the $\mathrm{IP}_{3}$-calcium signaling pathway that produces $\mathrm{IP}_{3}$ by hydrolyzing $\mathrm{PIP}_{2}$, was recruited to CD59-cluster rafts exclusively during their STALL periods (Fig. 2(5)(6)). The transient recruitment of a GFP-PLC $\gamma$ molecule to a CD59 cluster raft is shown in Fig. 5a. This result suggests that $\mathrm{IP}_{3}$ is produced from $\mathrm{PIP}_{2}$ only at the STALL site. Because the STALL lifetime (the exponential decay time) is $0.57 \mathrm{~s}$, the duration of PLC $\gamma 2$ recruitment has to be shorter than the STALL period. The actual measurement showed that the duration of GFP-PLC $\gamma 2$ recruitment was $0.25 \mathrm{~s}$ (median value), as shown in Fig. 5b. Since the turnover rate of PLC $\gamma$ is 70-200 per second (27), a single PLC $\gamma$ molecule could produce $20-50 \mathrm{IP}_{3}$ molecules during its stay at the STALLed CD59-cluster raft.

Since CD59-clustering-induced calcium mobilization was totally inhibited by heparin, an inhibitor of $\mathrm{IP}_{3}$ receptor on the ER membrane, the $\mathrm{IP}_{3}$ molecules generated at the STALLed CD59-cluster raft is likely to be entirely responsible for the rise of the cytoplasmic free calcium concentration (Fig. 2(7)). Therefore, we propose that the CD59-cluster raft in STALL is a key platform for transducing the extracellular CD59 signal to the intracellular $\mathrm{IP}_{3}$-calcium signal. Such mechanisms would have never been revealed without single-molecule observations.
D. CD59 クラスターラフトへの細胞内シグナル分子の一時的

リクルート

我々の研究室で開発した装置と方法論を用いることで, 個々の CD59 クラスターラフトと GFP 標識した細胞内シグナ ル分子（Lyn-GFP, Goi2-YFP, GFP-PLC $\gamma 2$ 2) の各々の 1 分子 づつを同時観察することを達成した（図 4 には CD59 クラス ターラフトへの Lyn-GFPの一時的リクルートを示してい る)。この困難な実験は, 相当に収穫も大きく, 以下のような 興味深い観察をもたらした（図 2, 図 4)。拡散しているCD59 クラスターラフトには Lyn 分子が恒常的に, 頻繁にリクルー トされてきていた（図 2(3))。Goi2 も CD59 クラスターラフ トヘリクルートされ， Goi2 のリクルートの直後に CD59 クラ スターラフトの一時停留 (STALLing) が誘起された。Goi2 は直接に SFK を活性化することが知られているので, Goi2 と Lyn 分子が同じ CD59 クラスターラフトヘリクルートされる ときに（図 2(3))，Goi2 は Lyn に結合し，Lyn を活性化する と考えられる。活性化された Lyn が未知の貫通型タンパク質 $\mathrm{X}$ (図 2(4) ) をリン酸化し，これが CD59 クラスターラフト のアクチン線維への結合を誘起し，CD59 クラスターラフトの 運動を止める，すなわち，CD59 クラスターラフトの STALL を誘起している（図2(5)）と考えている。

しかも, $\mathrm{PIP}_{2}$ を加水分解して $\mathrm{IP}_{3}$ を産生する $\mathrm{IP}_{3}$-カルシ ウムシグナル経路に関わっている酵素のPLC $\gamma 2$ が, CD59 ク ラスターラフトへSTALLの期間中にだけリクルートされて いた（図 2(5) (6))。GFP-PLC $\gamma$ のCD59 クラスターへのリク ルートを図 $5 \mathrm{a}$ に示す。このことは STALL 領域でのみ $\mathrm{PIP}_{2}$ から $\mathrm{IP}_{3}$ が産生されていることを示唆している。 STALLの継 続時間（指数関数の減衰期間）は平均 0.57 秒であったので, PLC $\gamma 2$ のCD59 クラスターラフト上での滞在時間は, さらに 短いはずである。実際に測定すると，平均で 250 ミリ秒（中 央值）であった（図 $5 b$ b) P P C $\gamma$ のターンオーバー速度は 70200/秒であるので(27), STALLを起こしているCD59 クラス ターラフトヘリクルートされている間にPLC $\gamma$ の 1 分子は, 20-50 個の $\mathrm{IP}_{3}$ 分子を産生するだろう。

CD59 クラスターラフトが誘起したカルシウム応答は, $\mathrm{ER}$ 膜上の $\mathrm{IP}_{3}$ 受容体の阻害剤であるへパリンによって完全に 阻害されたので, STALLを起こしているCD59 クラスターラ フトに打いて産生される $\mathrm{IP}_{3}$ 分子が, 細胞質内のフリーカル シウム濃度上昇の原因であると考えられる（図 2(7))。従っ て, 我々は STALL 中の CD59 クラスターラフトは細胞外の $\mathrm{CD} 59$ のシグナルを細胞内の $\mathrm{IP}_{3}-$ カルシウムシグナルにをで 変換するプラットフォームであると提案したい。このような 機構は, 1 分子観察以外では全く見出せなかっただろう。 

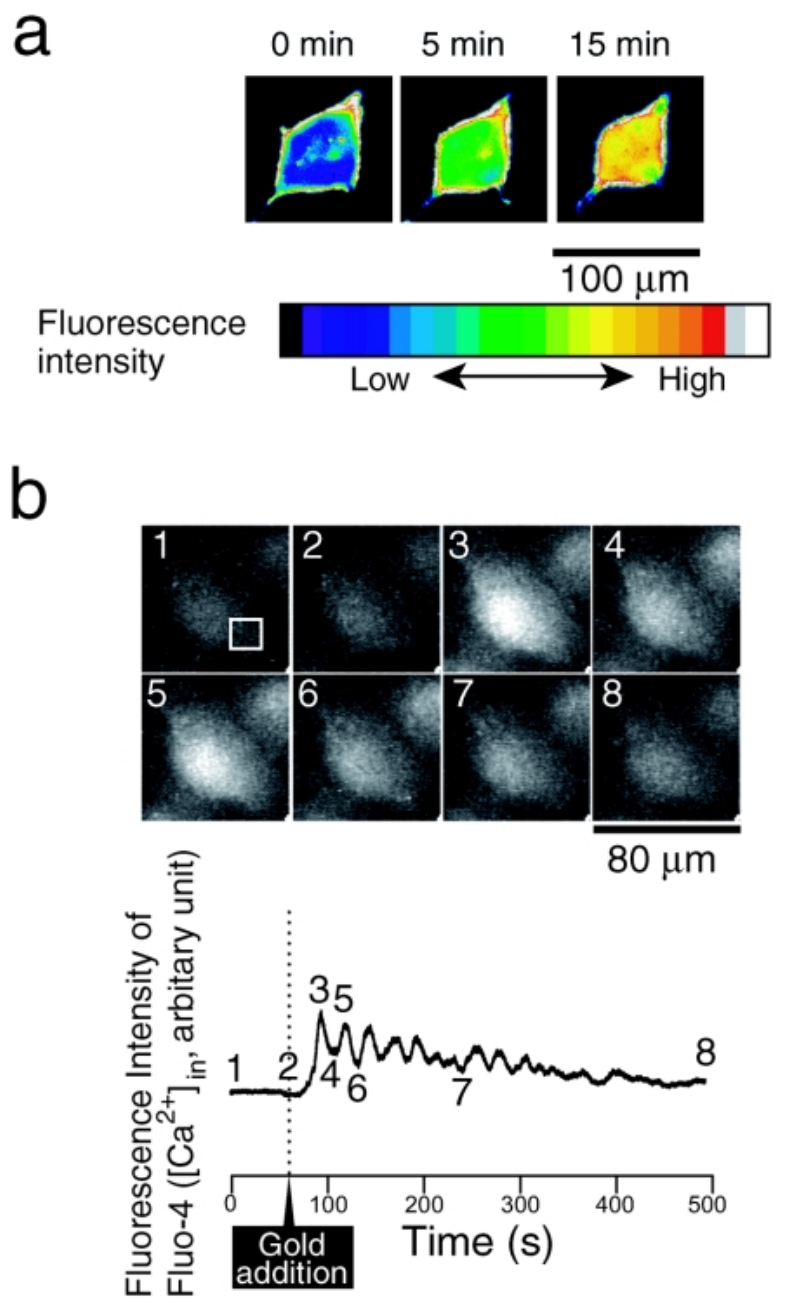

Fig. 6. Long lasting Bulk signaling by CD59-cluster rafts. (a) Increase of the cytoplasmic $\mathrm{IP}_{3}$ concentrations induced by CD59 clusters, as observed by the epi-fluorescence imaging of the PH domain (from PLC $\delta 1$ )-GFP expressed in T24 cells. CD59 clustering was induced by the addition of IgG-Gold particles. (b) (Top) Typical time-dependent changes of the cytoplasmic $\mathrm{Ca}^{2+}$ concentrations after the addition of IgG-Gold particles (via the release of $\mathrm{Ca}^{2+}$ from ER through $\mathrm{IP}_{3}$ receptor), as observed by epi-fluorescence microscopy of fluo4 in live T2 4 cells. The numbers in the images correspond to the numbers shown in the bottom trace. (Bottom) The fluorescence intensity of Fluo- 4 measured in the box of the first image of the top figure $(24 \times 24$ pixels $)$, plotted as a function of time.

\section{E. Digital-like signal transduction in raft signaling}

As described in the previous section, the bulk $\mathrm{IP}_{3}$ calcium signaling lasts for an order of $1000 \mathrm{~s}$ (Fig. 6a and b), whereas each event of PLC $\gamma$ recruitment (and $\mathrm{IP}_{3}$ production) lasts for only about $0.25 \mathrm{~s}$ (Fig. 5b). Namely, the periods for individual signaling events are severalthousand fold shorter than the duration of the bulk signaling. This was totally unexpected when we started the present research. When we initiated this work, we, without deep thoughts on the durations of individual signaling events, somehow assumed that the duration of each signaling event might be perhaps 10 -fold shorter than the bulk
E. ラフトにおけるディジタル式シグナル変換

前のセクションで述べたように, バルクの $\mathrm{IP}_{3}$-カルシウ ムシグナルは 1000 秒のオーダーで継続するが（図 6a と b), $\mathrm{PLC} \gamma$ のリクルート（と $\mathrm{IP}_{3}$ の産生）は，わずか 0.25 秒しか 続かなかった（図 5b)。つまり，個々のシグナルの起こる期 間は，バルクシグナルの起こる期間の数千倍も短い。このこ とは，当初全く予想だにしないことであった。我々は，研究 開始時には，あまり深く考えることもなしに，個々のシグナ ルの起こる期間はバルクシグナルよりもたぶん 10 倍程度短い くらいであううと考えていた。安定化ラフトを作り出し, 


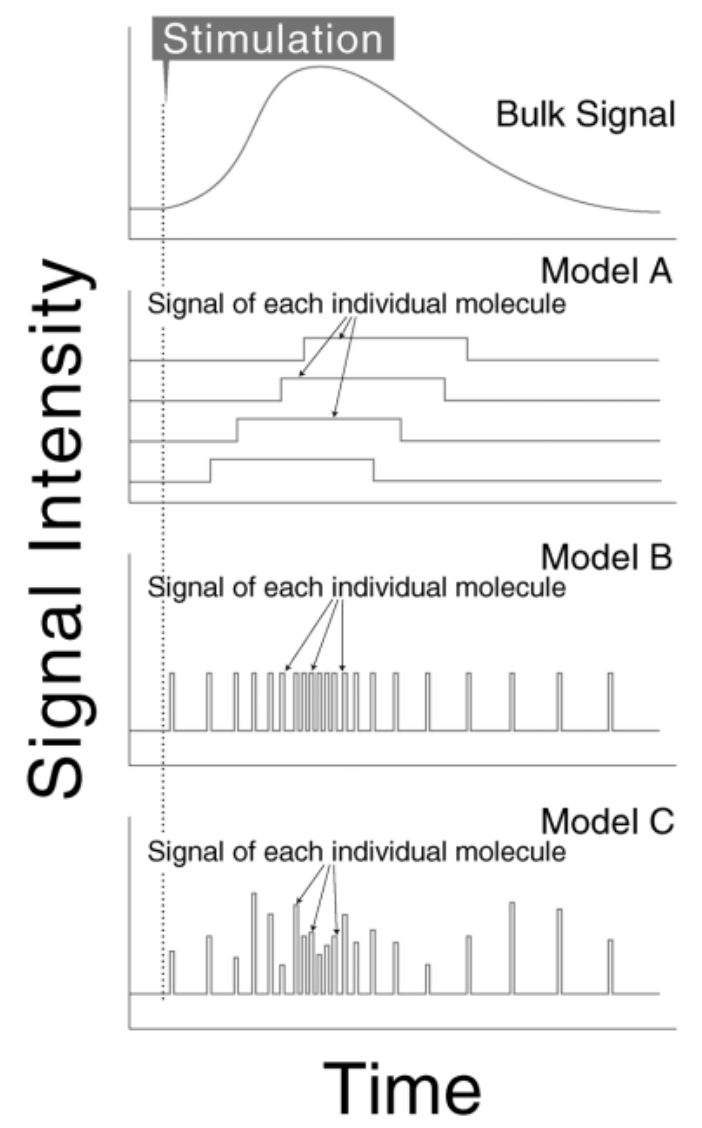

Fig. 7. Schematic diagram showing how the bulk signal is produced from the individual signaling events. See the text for details.

duration. The cell spends so much resources and energy to create stabilized rafts, and then turn them into STALLed rafts, and finally to bring $\mathrm{PLC} \gamma 2$ and $\mathrm{PIP}_{2}$ in the STALLed rafts to generate $\mathrm{IP}_{3}$. Therefore, if efficiency were the matter of importance, it would be much better to keep the STALLed rafts in the same place, and keep recruited PLC $\gamma 2$ molecules in the same STALLed raft so that more and more $\mathrm{IP}_{3}$ molecules are generated, as long as the supply of PIP2 at the same place is not limited. The diffusion of CD59-cluster rafts can be considered as spatial sampling, which might also be necessary for compensating the limited supply of $\mathrm{PIP}_{2}$ at the same place. Or perhaps, $\mathrm{IP}_{3}$ signaling system is designed so that the bulk signal is formed as the sum of short digital pulses rather than the sum of long-lasting signaling events of the recruitment of PLC $\gamma 2$ to the STALLed CD59-cluster raft, because the digital-like signaling is simply a better signaling system (although we will still have to find out why digital signaling based on individual pulse-like signals works better in the cell environment).

See Fig. 7. The top panel shows the time course of the bulk signal. Model A (second panel) describes the
STALL を誘起し, 最終的に STALLを起こしているラフト中 でPLC $\gamma$ と $\mathrm{PIP}_{2}$ に $\mathrm{IP}_{3}$ を産生させるために, 細胞はかなり多 くの資源とエネルギーを費やしている。従って，もし効率が 重要な問題であれば，同じ場所に STALLを起こしているラ フトを保持して，そこにリクルートされたPLC $\gamma$ 分子を保持 している方が, 同じ場所で $\mathrm{PIP}_{2}$ の供給が続く限り, より多く の $\mathrm{IP}_{3}$ が産生されるので，良いであろう。CD59 クラスターラ フトが拡散することは, 同じ場所だけでは限られている $\mathrm{PIP}_{2}$ の供給を補填するのに必要な空間サンプリングだと考えるこ ともできる。あるいは IP \} _ { 3 } \text { シグナル系は, STALLを起こして } いるCD59 クラスターラフトへPLC $\gamma 2$ のリクルートが長時間 続く場合のシグナルの総和よりも, 短いディジタル式パルス 状シグナルの総和として, バルクシグナルが形成されるよう にデザインされているのであろう。この理由は単にディジタ ル式シグナルがより良いシグナル系であるからである（個々 のパルス状シグナルに基づくディジタル式シグナルが細胞の 環境の中でうまく機能する理由を我々は見つけなければなら ないが)。

図7を見ていただきたい。一番上のパネルはバルクシグ 
"complex integration model", where each individual signaling event lasts for a length comparable to that for the bulk signaling. In Model A, to realize the desired level of the bulk signal and its time course, complicated integration of individual signals is required. How the cell can manage such complicated integration has remained enigmatic. Model B (third panel) describes the "simple summation model", where each single-molecule event occurs like a digital pulse, as compared with the duration of the bulk signal. These pulses can then simply be added up to generate the desired bulk signal, without the need for complicated integration.

Presently, our working hypothesis for the raft signaling is digital signaling based on pulse-like single events, with variable durations and signal intensities, as shown in Model C (bottom panel). This is similar to the "fuzzy digital control system" in the field of system electronic engineering. Further clarification of this interesting problem would certainly be needed.
ナルの経時変化を示している。モデル A（2 番目のパネル）は 個々のシグナルがバルクシグナルに匹敵するくらい長く続い ている「複雑な積分モデル」を表している。モデル A では, シグナル強度も時間も一致する上のバルクシグナルのグラフ を作るのに，個々のシグナルの複雑な積分を必要とする。そ れを，細胞がどのようにやっているのかは疑問であった。モ デル B（3 番目のパネル）は個々の 1 分子反応が，バルクシグ ナルの期間と比較してディジタル式にパルス状に起こるとい う「単純な総和モデル」を表している。複雑な制御の必要な くして, これらのパルスを単純に足し合わせることで望みの 強度のバルクシグナルを生み出すことが可能である。

現在, ラフトシグナルの我々の作業仮説は, モデル C （一番下のパネル）に示すようにシグナルの期間も強度もばら ついているパルス状シグナルに基づいたディジタル式シグナ ルである。これは, システム電子工学の分野でいう「ファジー ディジタル制御システム」に近い。この興味深い問題のさら なる解明が確かに必要であろう。

\section{References}

1. Simons, K., and van Meer, G. (1988) Biochemistry 27, 6197-6202

2. Simons, K., and Ikonen, E. (1997) Nature 387, 569-572

3. Kabayama, K., Sato, T., Saito, K., Loberto, N., Prinetti, A., Sonnino, S., Kinjo, M., Igarashi, Y., and Inokuchi, J. (2007) Proc. Natl. Acad. Sci. U.S.A. 104, 13678-13683

4. Iwabuchi, K., Zhang, Y., Handa, K., Withers, D. A., Sinay, P., and Hakomori, S. (2000) J. Biol. Chem. 275, 15174-15181

5. Todeschini, A. R., Dos Santos, J. N., Handa, K., and Hakomori, S. I. (2008) Proc. Natl. Acad. Sci. U.S.A. 105, 1925-1930

6 Yuyama, K., Sekino-Suzuki, N., Sanai, Y., and Kasahara, K. (2007) J. Biol. Chem. 282, 26392-26400

7. Suzuki, K., Baba, J., Tohyama, K., Kanai, K., Kuwabara, S., Hirata, K., Furukawa, K., Furukawa, K., Rasband, M. N., and Yuki, N. (2007) Glia 55, 746-757

8. Nishio, M., Fukumoto, S., Furukawa, K., Ichimura, A., Miyazaki, H., Kusunoki, S., Urano, T., and Furukawa, K. (2004) J. Biol. Chem. 32, 33368-33378

9. Itoh, K., Sakakibara, M., Yamasaki, S., Takeuchi, A., Arase, H., Miyazaki, M., Nakajima, N., Okada, M., and Saito, T. (2002) J. Biol. Chem. 168, 541-544

10. Nakayama, H., Yoshizaki, F., Pronetti, A., Sonnino, S., mauri, L., Takamori, K., Ogawa, H., and Iwabuchi, K. (2008) J. Leukoc. Biol. 83, 728-741

11. Fujita, A. Cheng, J., Hirakawa, M., Furukawa, K., Kusunoki, S., and Fujimoto, T. (2007) Mol. Biol. Cell 18, 2112-2122

12. Ishitsuka, R., Yamaji-Hasegawa, A., Makino, A., Hirabayashi, Y., and Kobayashi, T. (2007) Biophys. J. 86, 296-307

13. Nagatsuka, Y., Tojo, H., and Hirabayashi, Y. (2006) Methods Enzymol. 417, 155-167

14. Yanagisawa, K. (2008) Biochim. Biophys. Acta 1768, 1943-1951

15. Waheed, A. A., Shimada, Y., Heijnen, H. F., Nakamura, M., Inomata, M., Hayashi, M., Iwashita, S., Slot, J. W., and OnoIwashita, Y. (2001) Proc. Natl. Acad. Sci. U.S.A. 98, 4926-4931

16. Sharma, P., Varma, R. Sarasij, R. C. Krishnamoorthy, I. G., Rao, M., and Mayor, S. (2004) Cell 116, 577-586

17. Stefanova, I., Horejsi, V., Ansotegui, I. J., Knapp, W., and Stockinger, H. (1991) Science 254, 1016-1019

18. Kinoshita, T., Inoue, N., and Takeda, J. (2008) Annu. Rev. Med. 47, 1-10

19. Kusumi, A., Koyama-Honda, I., and Suzuki, K. (2004) Traffic 5, 213-230

20. Suzuki, K., Ritchie, K., Kajikawa, E., Fujiwara, T., and Kusumi, A. (2005) Biophys. J. 88, 3659-3680

21. Fujiwara, T., Ritchie, K., Murakoshi, H. Jacobson, K., and Kusumi, A., (2002) J. Cell Biol. 157, 1071-1081

22. Murakoshi, H., Iino, R., Kobayashi, T., Fujiwara, T., Ohshima, C., Yoshimura, A., and Kusumi, A. (2004) Proc. Natl. Acad. Sci. U.S.A. 101, 7317-7322

23. Suzuki, K. G. N., Fujiwara, T. K., Sanematsu, F., Iino, R., Edidin, M., and Kusumi, A. (2007) J. Cell Biol. 177, 717-730

24. Suzuki, K. G. N., Fujiwara, T. K., Edidin, M., and Kusumi, A. (2007) J. Cell Biol. 177, 731-742

25. Suzuki, K., Sterba, R. E., and Sheetz, M. P. (2000) Biophys. J. 79, 448-459

26. Suzuki, K., and Sheetz, M. P. (2001) Biophys. J. 81, 2181-2189

27. Wahl, M. I., Jones, S., Nishibe, S., Ohee, S. G., and Carpenter, G. (1992) J. Biol. Chem. 267, $10447-10456$. 


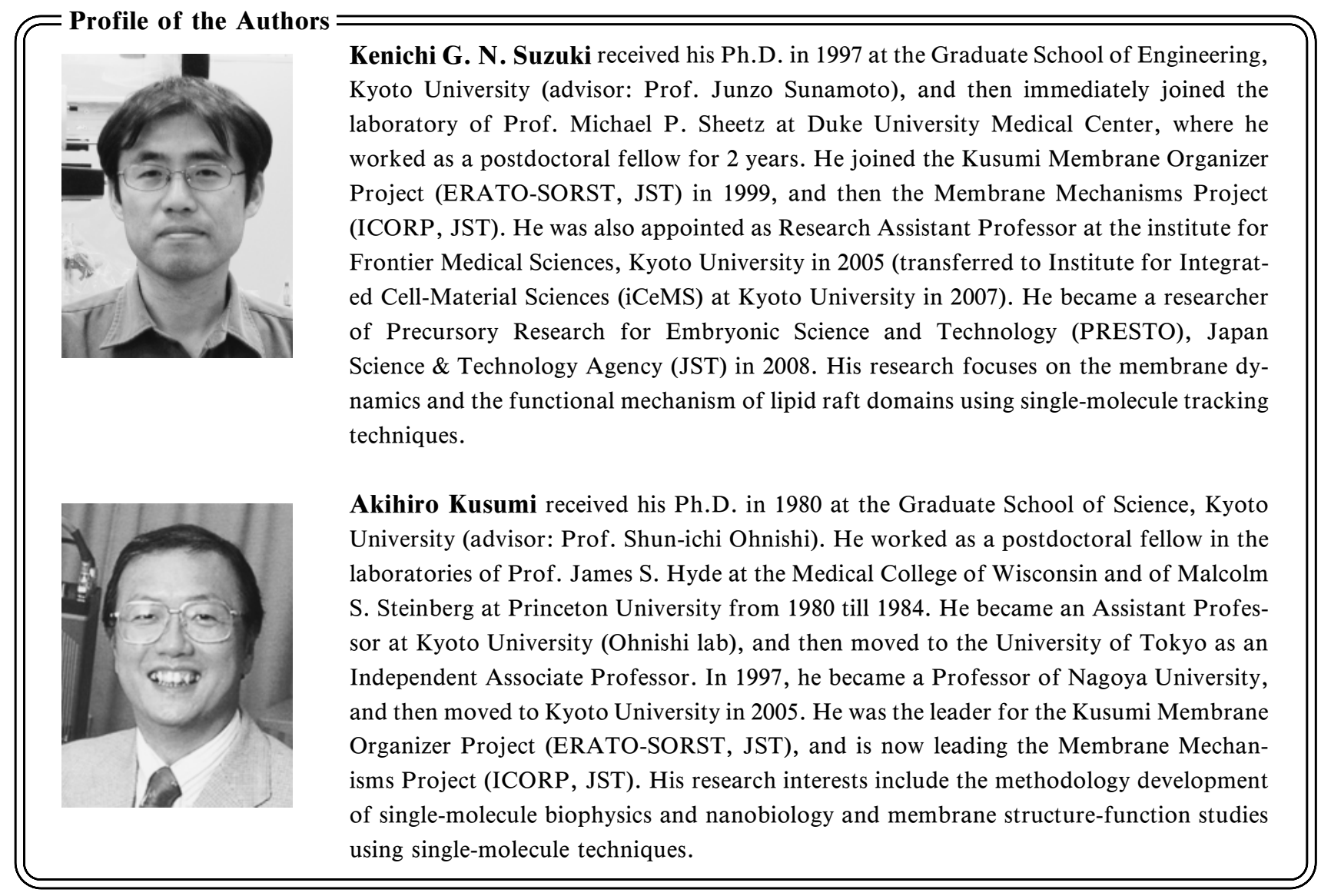

